\title{
SUBALTERN PORTRAYALS \\ IN THE HUNGER GAMES: MOCKINGJAY PART 1 MOVIE
}

\author{
Indah Megawati
}

\author{
UIN Alauddin Makassar \\ indaahmegawati@gmail.com
}

\begin{abstract}
This research discussed about Subaltern Portrayal in The Hunger Games: Mockingjay Part 1 Movie produced in 2014 November which aimed to find out the social and political aspect in The Hunger Games: Mockingjay Part 1 Movie. The source of data was The Hunger Games: Mockingjay Part 1 Movie which represented subaltern. The theory used in this thesis was Gramsci's Concept of Subaltern theory. The method used in the research was descriptive qualitative method. The researcher used note taking as instrument in order to get the valid data. As the result of the research, it was found that there were 23 subaltern portrayals in The Hunger Games: Mockingjay Part 1 Movie, they were 13 subaltern portrayals in social aspect and 10 subaltern portrayals in political aspect. The researcher concluded that the subaltern in social aspect were those who oppressed while in political aspect were those who tried to press their own claim.
\end{abstract}

Key Words: Subaltern, The Hunger Games: Mockingjay Part 1 Movie, Social, Political

\begin{abstract}
Abstrak
Penelitian ini membahas tentang Penggambaran Subaltern dalam The Hunger Games: Mockingjay Part 1 Movie yang diproduksi pada tahun 2014 November yang bertujuan untuk mengetahui aspek sosial dan politik dalam The Hunger Games: Mockingjay Part 1 Movie. Sumber data adalah The Hunger Games: Mockingjay Part 1 Movie yang mewakili subaltern. Teori yang digunakan dalam tesis ini adalah teori Gramsci's Concept of Subaltern. Metode yang digunakan dalam penelitian ini adalah metode deskriptif kualitatif. Peneliti menggunakan catatan sebagai instrumen untuk mendapatkan data yang valid. Sebagai hasil dari penelitian ini, ditemukan bahwa ada 23 penggambaran subaltern dalam The Hunger Games: Mockingjay Part 1 Movie, mereka adalah 13 penggambaran subaltern dalam aspek sosial dan 10 penggambaran subaltern dalam aspek politik. Peneliti menyimpulkan bahwa subaltern dalam aspek sosial adalah mereka yang tertindas sedangkan dalam aspek politik adalah mereka yang mencoba menekan klaim mereka sendiri.

Kata Kunci: Subaltern, The Hunger Games: Mockingjay Bagian 1 Film, Sosial, Politik
\end{abstract}

\section{INTRODUCTION}

Literature does not seem to be detached from daily life. The term 'literature' is more focused and restricted to merely imaginative works, which comes up from the imaginative mind of the story writers. Klarer (2004:14) stated that in most cases, literature is referred to as the entirety of written expression, with the restriction that not every written document can be categorized as literature in the more exact sense of the word. The definitions, therefore, usually include additional adjectives such as aesthetic or artistic to distinguish literary works from texts such as newspapers, scientific textbooks, magazines, legal documents, brochures and so on. 
Wellek and Warren (1984: 22) also stated that the term literature seems best if people limit it to the art of literature, that is, to imaginative literature. Literature is also produced by imagination of the author. Literature is not just a document of facts, it is not just the collection of real events though it may happen in the real life. To actualize author imagination, the author may use movie as literary work.

Movie, just like the other pieces of literature, is work of an art. Johnstone in Nikmah(2014: 1)stated that movie is complex text linguistic, structure, and visual codes which are arranged to produce the special meaning. It attempts to describe the world where people live. Arnheim(1957:28) further stated thus film, like the theater, provides a partial illusion. Up to a certain degree it gives the impression of real life. It is quite different with novel and poetry that the story are based on the text and need more time to get an understanding, even though movie is shorter and contain less texts, but movie needs more analysis to understand the hidden meaning behind less texts. Movie has several genres, such as comedy, drama, science-fiction and etc.

Science-fiction is a genre of movie that combines fiction and science. This genre usually tells about the future, alien and technology advance. According to Parkes (2013: 3), Science fiction appears to occupy a unique space in being able to critique the modern world without actually representing the modern world itself. One of science-fiction movies is The Hunger Games: Mockingjay Part 1.

The Hunger Games: Mockingjay Part 1 (2014) is anadapted science fiction movie from trilogy novel written by Suzanne Collins. The movie is directed by Francis Lawrence. The movie tell about a place or country which consists of thirteen districts with the center of government named capitol that is ruled by a dictator president who uses his power arbitrarily without considering the humanity. In social and political aspect, the capitol discriminated the people based on the wealth and power, where the people in districts lived in poverty and misery, while the capitol lived in harmony and prosperous. The district people also cannot speak for their rights and had to follow all of the rules that capitol made, if the districts did not follow the rules, the capitol directly slain them. The districts also may be recognized as subaltern.

Subaltern is a term for oppressed people that is created by Antonio Gramsci who means "inferior", dominated subject, or more familiar with them who as inferior Gandhi(2006:1). Subaltern is also defined as "they are not elites", and elites is "dominants group both outsider and indigenous" Guha (1982:60).

The subaltern classes refer fundamentally in Gramsci's words to any "low rank" person or group of people in a particular society suffering under hegemonic domination of a ruling elite class that denies them the basic rights of participation in the making of local history and culture as active individuals of the same nation. Referring to the definition, subaltern is those who cannot convey their aspirations and voices because there is a pressure from the superior. This is very contrary to the Qur'an verse which stated that all human beings are equal as reflected in surah AlHujurat: 13: 


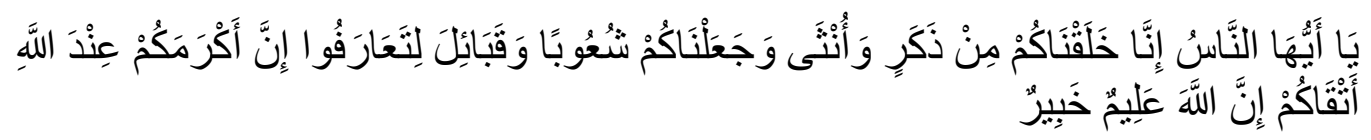

The translation:

O mankind, We created you from a man and a woman and made you nation and tribe to know one another. Verily the most honorable among you in the sight of Allah is the most piety among you. Allah is the Omniscient, the Knower. (Al-Hujurat: 13)

Based on the background above, the researcher was interested in analyzing subaltern portrayal through The Hunger Games: Mockingjay part 1 movie that was directed in 2014. Subaltern is still existing in real world, they live within limits and also the subaltern in movie is something new that is raised as a topic of discussion in a research or thesis especially in English and Literature department.

\section{PREVIOUS RESEARCHES}

These previous researches have some relationships with the research such as: Subaltern in Izzeldin Abuelaish's Novel I Shall Not Hate(2014), a research from JusmiatiusedOrientalism theory to described subaltern between Palestine and Israel in various aspect, such as social, economic, culture and political that existed in "I Shall Not Hate Novel". Jusmiati also wanted to know the intention of the author of represented subaltern in a novel. The result was, the researcherdescribed Palestine as eastern and Israel as western. Palestine as eastern was the one who became oppressed by Israel while Israel always looked Palestine as the eastern, the lower class that deserved to oppress. The economic factor was the main factor that causes Israel acted arbitrarily to Palestine.

"Speaking" Subalterns: A Comparative Study of African American and Dalit/Indian Literatures (2010), a research from Mantra Roy, used Postcolonial theory to examine the literatures of two marginalized groups, African Americans in the United States and Dalits in India. The result of the research was the researcher found that how two disparate societies, USA and India, were constituted by comparable hegemonic socio-economic-cultural and political structures of oppression that defined and delimited the identities of the subaltern in the respective societies. The superstructure of race in United State of America and caste in India informed, deformed, and complicated the identities of the marginalized along lines of gender, class, and family structure.

Sit Tsui (2005) on his research The Subaltern: A Critique of Representations of Rural Women in Contemporary Chinatried to read how urban intellectuals spoke for as well as drew a portrait of rural women by using GayatriSpivak's theory of the two kinds of representationproxy and portrait. As the result, the researcher concluded that rural people should transform themselves, sooner or later, from being disenfranchised migrants to legitimate citizens and skilled workers. In this way, urban intellectuals generally supported the national scenario of modernization and industrialization, in the process embracing the urbanist ideology of depicting the ideal 
agent of cosmopolitan society as a modern city worker.

Based on the previous researches above, the researcher found out similarity and differences between previous researches and this research. The similarity was on the theme, all of those researches focused on subaltern, so did with this research while the differences were on the content and theory. Most of those researches, usedfield studywhile this research used literary work (movie) as object that purposed to represent subaltern as portrayedin The Hunger Games: Mockingjay Part 1 Movie especially in social and politic aspect.

\section{THEORITICAL FRAMEWORK}

\section{A. Concept of Subaltern}

The notion of the subaltern was first referred by an Italian Marxist political activist Antonio Gramsci in his article "Notes on Italian History" which appeared as a part of his most widely known book Prisoner Notebooks written between 1929 and 1935. Subaltern, meaning 'of inferior rank', is a term adopted by Antonio Gramsci to refer to those groups in society who are subject to the hegemony of the ruling classes. Subaltern classes may include peasants, workers and other groups denied access to 'hegemonic' power of the elite.

The subaltern classes, by definition, are not unified and cannot unite until they are able to become a "State": their history, therefore, is intertwined with that of civils society, and thereby with the history of States and groups of States. In 'Notes on Italian history'Antonio Gramsci outlined a six-point plan for studying the history of the subaltern classes which included:

1) the objective formation of the subaltern social groups, by the developments and transformations occurring in the sphere of economic production; their quantitative diffusion and their origins in pre-existing social groups, whose mentality, ideology and aims they conserve for a time;

2) their active or passive affiliation to the dominant political formations, their attempts to influence the programs of these formations in order to press claims of their own, and the consequences of these attempts in determining processes of decomposition, renovation or neo-formation;

3) the birth of new parties of the dominant groups, intended to conserve the assent of the subaltern groups and to maintain control over them;

4) the formations which the subaltern groups themselves produce, in order to press claims of a limited and partial character;

5) those new formations which assert the autonomy of the subaltern groups, but within the old framework;

6) those formations which assert the integral autonomy, etc Gramsci(1971: 52). 
Gramsci claimed that the history of the subaltern classes was just as complex as the history of the dominant classes, although the history of the latter is usually that is accepted as 'official' history. For him, the history of subaltern social groups is necessarily fragmented and episodic Gramsci (1988: 54), since they are always subject to the activity of ruling groups, even when they rebel. Clearly they have less access to the means by which they may control their own representation, and less access to cultural and social institutions. Only 'permanent' victory (that is, a revolutionary class adjustment) can break that pattern of subordination, and even that does not occur immediately Ashcroft (2007: 212).

Gramsci's intentions when he first used the concept of the subaltern are clear enough to be given any farfetched interpretations. The only groups Gramsci had in mind at that time were the workers and peasants who were oppressed and discriminated by the leader of the National Fascist Party, Benito Mussolini and his agents. Gramsci became interested in the study of the subaltern classes of consciousness and culture as one possible way to make their voice heard instead of relying on the historical narrative of the state which is by the end the history of the ruling and dominant classes Louai (2011:2).

In Spivak's view Gandhi(2006:2) colonial literary studies can associate with the problem subaltern studies. That is the study of depressed society, must take the initiative, and holding an action over their voices were silenced. This kind of understanding, consciously or not much is coloring your literature world not a few works of literature in the colonial era which revealed the problem of subaltern. Spivak goes on to elaborate the problems of the category of the subaltern by looking at the situation of gendered subjects and of Indian women in particular, for 'both as an object of colonialist historiography and as a subject of insurgency, the ideological construction of gender keeps the male dominant'. For if 'in the context of colonial production, the subaltern has no history and cannot speak, the subaltern as female is even more deeply in shadow' Spivak (1985b: 27).

The term has been adapted to post-colonial studies from the work of the Subaltern Studies group of historians, who aimed to promote a systematic discussion of subaltern themes in South Asian Studies. It is used in Subaltern Studies' as a name for the general attribute of sub-ordination in South Asian society whether this is expressed in terms of class, caste, age, gender and office or in any other way' Guha (1988: vii). The group - formed by RanajitGuha, and initially including Shahid Amin, David Arnold, ParthaChatterjee, David Hardiman and GyanPandey - has produced five volumes of Subaltern Studies: essays relating to the history, politics, economics and sociology of subalternity 'as well as the attitudes, ideologies and belief systems in short, the culture informing that condition'. The purpose of the Subaltern Studies project was to redress the imbalance created in academic work by a tendency to focus on élites and élite culture in South Asian historiography. Recognizing that subordination cannot be understood except in a binary relationship with dominance, the 
group aimed to examine the subaltern 'as an objective assessment of the role of the élite and as a critique of élitist interpretations of that role'.

The subaltern are therefore not unified groups. The lack of unity among them is not intended but it is a prevalent condition. Their history, therefore, intertwined with what of civil society, and thereby with the story of state and group of state. No matter how heterogeneous subaltern groups may be, there is constantly unchanging character which defines the: that is, the notion of resistance to the imposed domination of the elite class Gramsci (1991). In the "Preface" to the first volume to the subaltern studies, Guha explained that the term of "subaltern" would be used by the authors in the series as a "general attribute of subordination in South Asian Society" however, Guha as not simply interested in examining question of subordination in classical Marxist framework defined by the logic of capital. Instead, he argued that condition of subaltern could be based on caste, age, gender, wealth, power and other ways, but not limited to class. Guha further stated that he was centrally interested in interpreting culture that he informed subalternity, while also addressing concern about history, politics, economics, and sociology. Needless to say, this was departure from Gramsci's own writings on the subaltern classes in his "Notes on Italian History", which according to Guha, had directly influenced the founding of his project. Subaltern today have attained a connotation which is more or less like being indigenous as they have become unorganized and marginalized in their own homeland.

One clear demonstration of the difference between the élite and the subaltern lies in the nature of political mobilization: élite mobilization was achieved vertically through adaptation of British parliamentary institutions, while the subaltern relied on the traditional organization of kinship and territoriality or class associations Gramsci (1991).

The former belongs to a dominant and directive social group; the latter to a group which is still subaltern, which has not yet gained consciousness of its strength, its possibilities, of how it is to develop, and which therefore does not know how to escape from the primitive phase Gramsci(2000: 208). When it comes to the representation of subalternity, Green argues, "Gramsci was concerned with how literary representations of the subaltern reinforced the subaltern's subordinated position. In historical or literary documents, the subaltern may be presented as humble, passive or ignorant, but their actual lived experience may prove the contrary. Hence, the integral historian has to analyze critically the way in which intellectuals represent the conditions and aspirations of the subaltern" Green (2000: 15). It is for this reason that the study of subaltern groups, in all their particularity, is of such importance for Gramsci. Thus, his interest in them is threefold: "he was interested in producing a methodology of subaltern historiography, a history of the subaltern classes, and a political strategy of transformation based upon the historical development and existence of the subaltern" Green (2000: 3). 
Gramsci's concept of subalternity is most often used for an analysis of a group's position, and in these analyses subalternity is usually assumed to be a negative condition, based on a lack, that needs to be overcome by a confrontation with the structures of power. Subalternity was not always a state of victimhood but was made so more often by historians or theorists who sought to impose pre-existing categories of analysis onto situations. In this scenario, subaltern groups are depoliticized or decontextualized. This way of thinking overlooks the subtleties in Gramsci's theory of hegemony, in which, if real social change is to occur, subalternity must be understood in its specific historical context, and the processes by which it is produced and reproduced exposed.

On the explanation above, there were several definitions of subaltern and the writer concluded that the subaltern is someone or group who is opposed by the upper and middle classes and very often by gender norms as well and also people may say subaltern are the lower class, inferior, and subordinated.

\section{B. Synopsis Mockingjay Part 1 Movie}

The Hunger Games: Mockingjay Part 1 is a science fiction movie released on November 2014 in United State. This movie is sequel from it first movie The Hunger Games (2012) and continue with The Hunger Games: Catching Fire (2013). The story is connected each other. After Katniss Everdeen as the victor of the 74th in The Hunger Games (2012) and become victor again of 75th Hunger Games in The Hunger Games: Catching Fire (2013), when the end of the second movie, Katnisshas destroyed the battle arena, she destroyed with all of her allies. She shoots the arena by using arrow and since that time all of the power in capitol is broke. The game stopped, Katniss is dying, so with another tribute. All of them were taking to the District 13 unless Peeta(Katniss boyfriend). Peeta was arrested by Capitol. Katniss and the other survivor is in District 13 which is convinced has been broke down. District 13 leads by President Alma Coin. Katniss got a medical treatment in there. Feeling better, she strolls around the District, she met her family, and also her friend. Then President Alma Coin was asking her to talk.

In district 13, she is asking to be the Mockingjay from President of Districts 13. Mockingjay is a symbol for against the capitol. The District 13 has a big plan for Capitol but first, she asking Katniss as propaganda to start the war against the Capitol. Katniss fulfill the request, she has been done some of propaganda to burn the districts spirits and also as an ultimatum for the Capitol.Someday, Katniss visited District 8. In District 8, there are so many helpless people. All of them count on her. Katniss feel pity and sad so deep to see them, finally she promises to save them all but not longer, the capitol bombed down the District 8 where full of helpless and sick people. Katniss directly put an arrow and also bombed down the Capitol jet. Since that day, the chaos was increased. The workers risk their lives to fight the Capitol's army. They make a trap for them. All of Panem became uncontrolled. Meanwhile, Katniss was asking the president of District 13 to save Peeta, so they plan a tactic to sneak outinto the Capitol without get caught. 
The attack day has come, the district attacks the power source of the capitol. They made it, the Capitol has no power, totally black out, the armies get in to the Capitol and found Peeta, they took Peeta to District 13. Peeta was savebut when Peeta in there, there is something wrong with him. He did not seem normal.Katniss went to check Peeta's condition but when she was in there,Peetadirectly attacked and chocked Katniss. Katniss was very stressed out because the Capitol has brain washed Peeta. Peeta have to get some medical treatment. Meanwhile, president Alma Coin prepare something bigger and massive for the Capitol and all of the Districts were preparing their selves for it and so do the Capitol. This movie stopped there because it still has sequel which is become a final story of the Districts against the Capitol.

\section{RESEARCH METHODOLOGY}

This chapter consisted of Research Method, Subject of The Research, Instrument of The Research, Procedure of Collecting Dataand Technique of Data Analysis.

\section{A. Research Method}

In this research, the researcher used descriptive qualitative method. Burns and Grove (2003:201) state that descriptive research is designed to provide a picture of a situation as it naturally happens. It may be used to justify current practice and make judgment and also to develop theories. It purposed to portray the subaltern in The Hunger Games: Mockingjay Part 1 (2014) movie.

\section{B. Data Source}

In this research, the researcher took the data from The Hunger Games: MockingjayPart 1 movie. The movie was released on November 2014 and directed by Francis Lawrence. Length of the movie was about an hour and fourty five minutes.

\section{Research Instrument}

The researcher used note taking as instrument in this researchto collect the data.Note-taking is a process that involves writing or recording what people hear or read in a descriptive way. This is often the first stage of the process of producing effective notes Neville(2006).In order to find the data easily, the researcherwrote down on notes to classify the important units or parts of film that were related to the problem and objective of the research.

\section{Data Collection and Analyzing Procedure}

In other to collect data, the researcher conducted the following proceduresin collecting data:

1. First, the researcher watched The Hunger Games:MockingjayPart 1 (2014)movie.

2. Second, the researcher took a note as an instrument to write down the data that were found.

3. Then, the researcher identifiedthe subaltern portrayal in the movie by using Concept of Subaltern Theory by Antonio Gramsci.

4. Finally, the researcher wrote down the data that were found in the movie. 


\section{E. Data Analysis Technique}

In this section, the researcher analyzed the data to know the subaltern that was portrayed in the movie. Afterwards, the researcher used Gramsci's theory about the concept of the subaltern to get an understanding in The Hunger Games: MockingjayPart 1 movie.

\section{FINDINGS}

In this section, the researcher presented the data analysis according to Antonio Gramsci's theory about concept of subaltern. Gramsci explained concept of subaltern into six points. Based on that, the researcher found that there are twoaspects of subaltern portrayal related to concept of subaltern namely social and political which are faced by the Districts in "The Hunger Games: Mockingjay Part 1" movie.

\section{a. Social}

Subaltern is a term for people who marginalized by the elites. Spivak $(28: 2003)$ stated subaltern is a distressed subject, the members of 'classes' of Antonio Gramsci, or more generally those at the inferior level. Subaltern has two characteristics namely, the emphasis and in it work a discrimination mechanism. Gramsci revealed three points of concept of subaltern that related to social aspect namely:

1. The objective formation of the subaltern social groups, by the developments and transformations occurring in the sphere of economic production; their quantitative diffusion and their origins in pre-existing social groups, whose mentality, ideology and aims they conserve for a time. As the first point of the theory, this point talk about subaltern that already existed in social group which is mean they are "born" as subaltern where they have a purpose and ideas to achieve. Based on that, the researcher found out that in the movie, Districts are the subaltern while Capitol is the elite. Capitol has been destroyed Districts by bombed down their houses, slain them that considered as traitor and tortured the Districts that revealed in the following extracts:

\section{Extract 1}

The life of districts was unlike the capitol life; especially Capitolhas bombed down the district 13 long time ago.As the result, people in there live in shadow, they have to hide and built a new life undergroundas reflected in the following extract:

Katniss : We were always told there was nothing left of 13 .

Colonel Boggs : Capitol bombed down the surface to rubble. But we're military, so we learned to survive down here, preparing, training. The war never stopped for us. (The Hunger Games: Mockingjay Part 1, 04:14 - 04:28) 


\section{Extract 2}

District 13 wasreformed district, because it has been destroyed by Capitol long time ago. It was quite creepy because it located underground. It consisted of some floors that looked like a basement prison.

\section{Extract 3}

Capitol has been destroyed some of the districts. District 8 was one of them, even though District 8 was still existed, but most of the people were dead and the others were suffered and in great pain as reflected in the following extract:

Commandant Paylor : We have a mass grave a few blocks west, but, I can't spare the manpower to move them yet. The Capitol's done everything they can to break us.

\section{Extract 4}

(The Hunger Games: Mockingjay Part 1, 43:55)

Social condition in District 8 was the pictures of the people who are suffering and struggling to survive. Everyone tried to help those who are injured as much as possible, although in conditions that are not possible.

\section{Extract 5}

District 12 was a place where Katniss live, her family and friends live in there too. The first District that Capitol destroys after the game stop was District 12 . Almost every people in District 12 were dead as reflected in the following extract:

Gale : Little past 9:00, we heard their trucks pullin' out, all of them. Every single peacekeeper and I knew what that meant. Me and a couple of guys from the mines, we started pulling people from their houses and tried to get them to the fence line but a lotta people were scared of the forest. So they headed up onto the road. Make a break for it that way. 915 of us made it to the fence. Then we watched as bombers circled back towards the road. They firebombed them as they ran away. 915 outta 10.000 .

(The Hunger Games: Mockingjay Part 1, 01:03:24 - 01:04:42)

\section{Extract 6}

Katniss, Gale and team visited District 12 to see what Capitol has done to their home. Katniss was very surprise because all the buildings were collapsed and there were a stack of corpses as reflected in the following extract (The Hunger Games: Mockingjay Part 1, 01:04:46). 


\section{Extract 7}

President Snow knows that Peeta was falling in love with Katniss. He also knew that Peeta wanted to do anything for her. To destroy Katniss life, the Capitol has been tortured and brain washed him as reflected in the following extract:

Beete : We don't know how long the Capitol's been doing this to Peeta. It's fear conditioning, enhanced with trackerjacker venom. You were stung you first games. Remember? The venom puts the subject in a dissociative state and they torture him with shocks and beatings, and strip down his identity and then all of that suffering and fear is redirected, associated with other memories or a person, to make her seem life-threatening. They turned him into a weapon, Katniss, to kill you.

(The Hunger Games: Mockingjay Part 1, 01:46:20 - 01:46:59)

2. The birth of new parties of the dominant groups, intended to conserve the assent of the subaltern groups and to maintain control over them. As the third point of theory, this point talked about the elites that want to keep controlling subaltern in social group. In the movie, the Capitol made some new rules and orders arbitrarily without Districts agreement. The rule also very tight, because whoever did not obey the rule, they will be punished without mercy. That things were done by Capitol to maintain their control over the District that revealed in the following extracts:

\section{Extract 8}

Life in the District just like life within limits, where the people cannot voice for their rights and have to follow the Capitol rules and whoever broke the rules, will get a punishment as reflected in the following extract:

President Snow : The criminals that kneel before you use symbol for the purpose of sedition which is why all images of The Mockingjay are now forbidden. Possessing them will be considered treason, punishable by death. Justice shall be served swiftly. Order shall be restored. To those who ignore the warnings of history, prepare to pay the ultimate price.

\section{Extract 9}

(The Hunger Games: Mockingjay Part 1, 17:22)

Capitol made a new order that the entire Mockingjay symbol were forbidden and for those who usedit will be punish. Onetime, some of the people used that symbol as a form of defianceand directly the peace keeper executed the dissident people as reflected in the following extract (The Hunger Games: Mockingjay Part $1,17: 43)$ 


\section{Extract 10}

Capitol knew that Katniss and the team were in District 8. President Snow ordered his military to destroy the District 8 because they support Katniss and used forbidden symbol; The Mockingjay as reflected in the following extract:

Military

: We can scramble hovercraft from the border of 11 .We may be able to target her (Katniss).

President Snow $\quad$ : (shook head) kill the wounded.Any association with the Mockingjay symbol is forbidden. Everyone inside that hospital has committed treason. Show them what it costs to be friends with Katniss Everdeen.

(The Hunger Games: Mockingjay Part 1, 47:16 -

\section{Extract 11}

The condition in the entire District were getting worse, the regulations were tightened. People were increasingly limited and they had to work extra hard because Capitol has added work hours arbitrary without the consent of the people as reflected in the following extract:

By order of President Snow, daily production quotas have been increased. All work shifts will be extended by an extra two hours. Failure to meet these quotas will not be tolerated.

(The Hunger Games: Mockingjay Part 1, 55:14 - 55:26)

\section{The formations which the subaltern groups themselves produce, in order} to press claims of a limited and partial character. This point of theory talked about subaltern that made a team or group of themselves to claim their own. In movie, some of district people gatheredhands to hands as a state of rebellion against Capitol by using the forbidden symbol, attacking the peacekeeper and putting down bombs into the power source of Capitol that located in District 2. The Districts encouraged themselves to rebel because they are tired of discrimination that happened in Panem as revealed in the following extracts:

\section{Extract 12}

Since daily production quotas have been increased, the workers had to work harder. The workers were desperate, so they used the Mockingjay symbol as form of rebellion even though it was forbid because they were tired of the injustices done by President Snow as reflected in the following extract (The Hunger Games: Mockingjay Part 1, 55:44) 


\section{Extract 13}

Live in each Districtwas unstable. The oppressed people began to rebel. They could not stand still anymore by keep following the rule. They encouraged their selves to fight against the Capitol because itwas better to die in a fight than live in fear as reflected in the following extract: (The Hunger Games: Mockingjay Part 1, 01:10:36)

\section{b. Political}

Subaltern not only told about social but also political. Isjwara (42:1995) stated that politics is either a struggle for power or as a technique of exercising powers. That meant, even though subaltern was the oppressed one in social group but they still looked for a way to gain power. Gramsci clarified subaltern that related to political aspect in some points, they were:

1. Their active or passive affiliation to the dominant political formations, their attempts to influence the programs of these formations in order to press claims of their own, and the consequences of these attempts in determining processes of decomposition, renovation or neo-formation.This point defined subaltern in political view where subaltern was the subject who tried to press their own claim by influenced the others. In movie, the Districts especially District 13 was going to start a revolution by affecting the other districts to fight against Capitol as revealed in following extracts:

\section{Extract 1}

After Katniss stop the game, she was taking into District 13, so with the others who against the Capitol including the game maker Plutarch Havensbee. District 13 leaded by President Alma Coin. President Alma Coin and Plutarch Havensbee had a plan to coup President Snow but they needed Katniss to join their plan because she was the face of Rebellion and known by entire Districts as reflected in the following extract:

President Coin : Are you aware of what's happened? When you fired your arrow at the force field, you electrified thenation. There have been riots and uprising and strikesin seven districts. We believe that if we keep this energy going we can unify the districts against theCapitol. But if we don't, if we let it dissipate, we couldbe waiting another 75 years for this opportunity.Everyone in $\mathbf{1 3}$ is ready for this.

(The Hunger Games: Mockingjay Part 1, 05:44 - 06:12) 


\section{Extract 2}

President Coin and Plutarch, explained to Katniss what their plans are. They wanted to make a series of propaganda clips to unify the entire districts and spread the message that the Mockingjay will join the revolution but Katniss refused because they left Peeta in the arena as reflected in the following extract:

President Coin : All we need now is the perfect message. Katniss, here's what we need to do. We need to show them that the Mockingjay's alive and well and willing to stand up and join this fight. Cause we need every districts to stand up to this Capitol the way you did.

Plutarch :So we're gonna shoot a series of propaganda clips, propos, I like to call them, on The Mockingjay. Spreads the word that we're gonna stoke the fire of this rebellion. The fire that The Mockingjay started.

Katniss : : You left him there. You left Peeta in that arena to die. Peeta was the one who was supposed to live.

President Coin : Miss Everdeen, this revolution is about everyone, it's about all of us. And we need a voice.

Katniss : : Then you should've saved Peeta.

(The Hunger Games: Mockingjay Part 1, 05:45 - 07:26)

\section{Extract 3}

In the first meeting with President Coin, Katniss refused the deal. She still worried about Peeta. In her room, she told her sister Prim about her worries then Prim gave her a suggestion to fileseveral conditions to President Coin.Finally Katniss met with President Coin and told her that she agree to join the fight with several conditions as reflected in the following extract:

Katniss : I've decided I'll be your Mockingjay but I have some conditions. Peeta and the other tribites, Peeta, Johanna Mason and Annie Cresta, will be rescued at the earliest opportunity. If and when Peeta is liberated, he will receive a full and unconditional pardon. No punishment will be inflicted and the same goes for the other Tributes.

(The Hunger Games: Mockingjay Part 1, 26:16 - 26:42) 


\section{Extract 4}

Katniss was officially became the symbol of rebellion (The Mockingjay). All of the rebellion teamcreated the propaganda video that to be broadcast in entire districts except Capitol as reflected in the following extract:

Plutarch : Okay, let's bring up the setting. Little wind. Okay Katniss, we're gonna start you down on one knee.

Katniss : Okay

Plutarch : And as you rise up, you're gonna hold your flag in the air and deliver your line. And remember you've just stormed the outskirts of the Capitol arm in arm with your brothers and sisters

(The Hunger Games: Mockingjay Part 1, 34:58 - 35:23)

\section{Extract 5}

Entire districts had been watched the propaganda clip and successful sparked the spirit of the people. One day, Katniss and team were on the river bank, they took a rest and enjoyed the view. Katniss heard the mockingjay's whistle, and one of the team asked her to sing a song. Inspired by the mockingjay bird, Katniss sang a song. Accidentally, that song became another propaganda that will be broadcast again as reflected in the following extract:

Plutarch : that line was originally "necklace of rope." I had it changed to "necklace of hope."

President Coin : is every district's seeing this?

Beete : yes.But not the Capitol. I designed this signal defense system for them.

(The Hunger Games: Mockingjay Part 1, 01:08:59 - 01:09:18)

\section{Extract 6}

Successfully broadcasted the propaganda song, it did not require a long time the song is sang by the whole people. Some of the rebels sang the song when fighting the peace keeper. They used the song as a march of struggle as reflected in the following extract: (The Hunger Games: Mockingjay Part 1, 01:09:30 01:09:45)

\section{Extract 7}

Propagandas by District 13 still continued. It happened when Capitol broadcasted a video to inform the Districts to stop the rebellion but District 13 immediately hijacked the Capitol's broadcast as reflected in the following extract:

Beete : We interrupt your daily regularly scheduled horse manure to bring you (propaganda song)

President Coin : that's it. That's our footage. Beete's in. he sees it. He sees our propo.

(The Hunger Games: Mockingjay Part 1, 01:12:57 - 01:13:13) 


\section{Extract 8}

The political situation between Capitol and District 13 were getting worse. After District 13 hijacked Capitol's broadcast, Capitol directly sent their military to bomb down the District 13. Luckily, everyone in there was safe. They made another video to inform the Panem that they survived from the attack as reflected in the following extract:

President Coin $\quad$ : I need you to do something for us. I need you to tell Panem we that we survived an attack by the Capitol

Katniss with no casualties and we remain fully operational. : okay

(The Hunger Games: Mockingjay Part 1, 01:24:14 - 01:24:26)

2. Those new formations which assert the autonomy of the subaltern groups, but within the old framework. The point of theory stated that subaltern formed a new formation but still in old framework. In movie, Katniss agreed to join the formation and become the symbol of rebellion, so President Coin announced that Katniss was in her team as revealed in the following extract:

\section{Extract 9}

The rebellion begins, the propaganda clip was ready to broadcast in entire district. President Coin also delivered a brief speech in front of the District 13 as reflected in the following extract:

President Coin : There is no progress without compromise. No victory without sacrifice. But I stand here with The Mockingjay to announce that our moment has arrived.

(The Hunger Games: Mockingjay Part 1, 53:30 - 53:44)

3. Those formations which assert the integral autonomy, etc. this point clarified the full rights of subaltern from those formation. In movie, President Coin stood in front of the Districts and said that revolution is coming. They will conquer Capitol and make a better new Panem. President Coin also clarified their demands and rights as revealed in the following extract:

\section{Extract 10}

All the districts are ready for war against the Capitol, people want a revolution in Panem. To keep the energy of revolution, President Coin deliver a passionate speech in front of the District 13 and state they are ready for war as reflected in the following extract:

President Coin : Good evening. Yesterday, I authorized a convert rescue mission inside the Capitol. I am pleased to announce that the Victors have been liberated! Let this day mark an historic charge with The Mockingjay and the Victors 
beside us, we have sent a clear message to the Capitol. That we will never again endure injustice. Today, a day on which we reunited family, friends, and loved ones. Let all of Panem come together. Not to battle for the amusement of the Capitol. But to join hands in this fight.Let today be the day we promise never to give up, never to give in until we have made a new Panem, where leaders are elected, not imposed upon us and where the districts are free to share the fruits of their labors and not fight one another for scraps! This new Panem is on the horizon. But we must take it for ourselves. The road there leads through the sharp mountains and deep ravines of District 2 . There in the heart of Panem's steepest mountain range lies the Capitol's principal military facility. We can conquer this stronghold because we are one people, one army, one voice. Because today is our new beginning. Today we have freed the Victors. Tomorrow, Panem!

(The Hunger Games: Mockingjay Part 1, 01:47:42 - 01:50:09)

Based on the findings, the researcher concluded that The Hunger Games: Mockingjay Part 1 movie portrayed subaltern. The subaltern portrayals included social and political aspects. The subaltern portrayals were dominated by social aspect. Then, it was followed by political aspect.

\section{DISCUSSION}

Based on the findings above, the researcher would like to give further description and explanation about the subaltern which portrayed in The Hunger Games: Mockingjay Part 1 movie.

Concept of subaltern that suggested by Antonio Gramsci consisted of six points. In this research, the researcher used all of the points in concept of subaltern because The Hunger Games: Mockingjay Part 1 movie contained all of those points. In The Hunger Games: Mockingjay Part 1 movie, it was found 23 subaltern portrayals which consisted of 13 in social aspect and 10 in political aspect. All those data analysis further explained as follows:

a. Social

Based on Gramsci's theory, concept of subaltern was divided into three points in social aspect, they were the first point, third and fourth point of the concept of subaltern as explained in chapter II.The first point was "the formation that made by the subaltern in social groups. Subaltern also has ideology, purpose and ideas to achieve" In the first point of theory, the researcher found seven extracts, they were (Extract 1), (Extract 2), (Extract 3), (Extract 4), (Extract 5), (Extract 6) and (Extract 7). 
From the findings, it could be seen the first point of concept of subaltern was the highest number of subaltern portrayals in The Hunger Games: Mockingjay Part 1 movie. This first point was mostly portrayed in the movie because it showed that the Districts as subaltern is pre-existing since the first sequel of the movie 'The Hunger Games 2012'. Subaltern in this movie described as those who have to live in hiding, just like District 13 that have to build a new life in underground after Capitol has been bombed down the surface. For example, "Capitol bombed down the surface to rubble. But we're military, so we learned to survive down here, preparing, training". The statement was made by Colonel Boggs in the extract 1.

The next point of concept of subaltern in social aspect was the third point. The third point was "the intention of the elite or dominant groups to keep controlling the subaltern". In the third point of theory, the researcher found four extracts, they were (Extract 8), (Extract 9), (Extract 10) and (Extract 11).

Based on the findings, it could be seen the third point of concept of subaltern was the second highest number of subaltern portrayals in The Hunger Games: Mockingjay Part 1 movie. This point was portrayed in the movie because it showed that Capitol as elite make a new rule and order which was still intended to have a full control of the District so the District cannot rebel anymore and also to prove that they had no mercy for those who broke the rules. For example, "Possessing them will be considered treason, punishable by death". The statement was made by President Snow in extract 8 .

The last point in social aspect was the fourth point. The fourth point was "subaltern formed a formation by them in order to demand their rights and also speak for their own importance". In the fourth point, the researcher found two extracts, they were (Extract 12) and (Extract 13).

The findings shown that the fourth point of concept of subaltern was the least number of subaltern portrayals in The Hunger Games: Mockingjay Part 1 movie. This point was portrayed in the movie because it showedthat the workers as subaltern formed a new group by them to start rebel by using the forbidden symbol and putting bombs into the Capitol to stop injustice.

\section{b. Political}

Based on Gramsci's theory, concept of subaltern in political aspect consisted of three points. They were the second point, fifth and sixth point. The second point was "the effort of subaltern in social groups to effect the other who also as subaltern to claim their own and as an attempt to start a neo formationand revolution in their system". In the second point, the researcher found eight extracts, they were (Extract 1), (Extract 2), (Extract 3), (Extract 4), (Extract 5), (Extract 6), (Extract 7) and (Extract 8).

As reflected in the findings, the second point of concept of subaltern was the highest number of subaltern portrayals in The Hunger Games: Mockingjay Part 1 movie. This second point was mostly portrayed in the movie because it 
showedthat through politic, District 13 tried to affect all of the Districts to join the fight against the Capitol. For example, "We need to show them that the Mockingjay's alive and well and willing to stand up and join this fight. Cause we need every districts to stand up to this Capitol the way you did. "The statement was made by President Coin in extract 2.

The next point of concept of subaltern in political aspect was the fifth point. The fifth point was "the formation that has been created by the subaltern before, tried to claim their own but not fully rights or partially". In the fifth point, the researcher only found one extract, it was (Extract 9).

It could be seen from the findings that the fifth point of concept of subaltern was the least number of subaltern portrayals in The Hunger Games: Mockingjay Part 1 movie. This fifth point was portrayed in the movie because it showedthat District 13 was formed a new formation with Katniss as the face of rebellion against Capitol but still had a limit because all of the Districts have not join the fight. For example, "But I stand here with The Mockingjay to announce that our moment has arrived". The statement was made by President Coin in extract 9.

The last point in political aspect was the sixth point. The sixth point was "the formation that formed by the subaltern were asserting their full rights or autonomy in government system". In the sixth point, the researcher only found one extract, it was (Extract 10).

The findings shown, the sixth point of concept of subaltern was the least number of subaltern portrayals in The Hunger Games: Mockingjay Part 1 movie. This sixth point was portrayed in the movie because it showed that President Coin announced a passionate speech that stated the revolution was coming, they will create a new Panem that will have a new system of government where the leaders were elected and will fulfill their duties for people, not for their own importance. For example, "Let today be the day we promise never to give up, never to give in until we have made a new Panem, where leaders are elected, not imposed upon us and where the districts are free to share the fruits of their labors and not fight one another for scraps". The statement was made by President Coin in extract 10.

Based on the previous findings by Jusmiati (2014) used Orientalism theory by Edward Said to analyze the subaltern representation in Novel I Shall Not Hate by Abuelaish's in some aspects. She found there were four aspects of subaltern representation in the novel such as: social, economic, political, culture. Jusmiati also represented subaltern as those who oppressed by the elites in social and political aspect.

Sit Tsui (2010) the researcher represented rural woman as subaltern in China by using Gayatri chakravorty Spivak's theory, and he found subaltern was powerless and had to transformed to be better in social live, they had to upgraded their selves so they will no longer as subaltern. The last previous findings by 
Mantra Roy (2010) used Postcolonial theory, he compared between two literatures in subaltern view that contain social and political content.

From those three previous findings that discussed about subaltern are different from those found by researcher in The Hunger Games: Mockingjay Part 1 movie. The difference was on the theory. It means that the same aspects did not mean that the subaltern portrayals would be the same because it analyzed with a different theory. The researcher found the aspects of subaltern portrayals in The Hunger Games: Mockingjay Part 1 movie by Gramsci theory were two: social and political.

\section{CONCLUSION AND SUGGESTION}

\section{A. Conclusion}

In "The Hunger Games: Mockingjay Part 1" movie, the researcher found the Districts as subaltern of Panem inhabitants who were portrayed by the director in the storyline. There were two aspects that portray subaltern through the Districts, they are: social and political. Socially, the Districts were pre-existing in social groups as subalternand became the one who oppressed, suffer and discriminated by the Capitol. It proved that subaltern wasmarginalized, they became the victim of oppression. The Districts also powerless because the Capitol keep attacking them and destroyed their lives. Politically, the Districts tried to rebel by doing some propaganda and make a new formation among them to unified entire Districts against Capitol, to claimtheir own rights because all of the Districts were tired with Capitol.The District also demand a revolution, a new system of government that standfor people importance.

\section{B. Suggestion}

Portraying subaltern not only in two aspects, especially in a movie that might be contained more aspects to analyze, thus the readers should learn more about subaltern related to concept of subaltern. The researcher also believed that the movie could be explored deeper. Moreover, The Hunger Games: Mockingjay Part 1 movie was a great movie that could be analyzed from various points of view. Finally, I suggested that findings could be used as a recommendation for another researcher in order to useanother literary work as the object of the study in portraying subaltern. 


\section{REFERENCES}

Al-Quran and The Translation. 2015. Al-Hujurat: 13. Jakarta: Indonesia Religion Department.

Arnheim, Rudolf. 1957. Film Is Art. Los Angeles: University of California Press.

Ashcroft, Griffiths and Tiffin. 2007.Post-Colonial Studies: The Key Concepts Second Edition. Madison Avenue, New York: Routledge.

Burns, N. \& Grove, S.K. 2003. Understanding Nursing Research. 3rd ed. Philadelphia: Saunders Company.

Deutsch, M. 2006. A Framework For Thinking About Oppression And Its Change. Netherland: Social Justice Research.

Gandhi, Leela.2006. Post Colonialism Theory: Attempts To Undermine Western Hegemony. Yogyakarta: Qalam.

Gandhi, Leela. 2006. Affective Communities: Anticolonial Thought, Fin-de-Siècle Radicalism, and the Politics of Friendship. Durham: Duke University Press.

Gramsci, A. 1971. Selections from the Prison Notebooks, edited and translated by Quintin Hoare and Geoffrey Nowell Smith. London: Lawrence and Wishart.

Gramsci, A. 1988.A Gramsci Reader: Selected Writings 1916-1935,edited byDavid Forgacs. London: Lawrence \&Wishart.

Gramsci, A. 1991.Prison Notebooks. New York: Columbia University Press.

Green, M. 2000. Gramsci Cannot Speak: Presentations and Interpretations of Gramsci's Concept of the Subaltern.

Guha, R. 1982. Subaltern Studies I: Writings on South Asian history and society. Delhi: Oxford University Press.

Guha, R. and G. C. Spivak. 1988. Selected Subaltern studies. New York: Oxford University Press.

Jusmiati.2014. Subaltern in IzzeldinAbuelaish's Novel I Shall Not Hate.Makassar: Alauddin State Islamic University.

Humanities Council. 2009. Defining The Humanities-A Work in Progress. Washington, D.C: Humanities Council.

Isjwara, F. 1995. PengantarIlmuPolitik. Bandung: BinaCipta.

Klarer, Mario. 2004. An Introduction To Literary Studies: Second Edition. London and New York: Routledge.

Lawrence, Francis. 2014. The Hunger Games: Mockingjay Part 1. USA: Lionsgate Pictures.

Louai, El Habib. 2011. Retracing the concept of the subaltern from Gramsci to Spivak: Historical developments and new applications. Morocco: Ibn-Zohr University.

Neville. 2006. Note Taking or Note Making?.London: University of Leeds.

Nikmah, Hidayatun. 2014. The Representation Of Heroine's Myth By "Katniss" In The Hunger Games Movie. Jogjakarta: SunanKalijaga Islamic State University of Jogjakarta. 
Parkes, Michael. 2013. Science Fiction Cinema: One Day Course. United State of America.

Roy, Mantra. 2010. "Speaking" Subalterns: A Comparative Study of African American and Dalit/Indian Literatures. SouthFlorida: University of South Florida.

Spivak, G. 1985b. 'Can the Subaltern Speak? Speculations on WidowSacrifice',Wedge(7) 8 (Winter/Spring). Cited in Ashcroft et al1995.

Tsui, Sit. 2005. The Subaltern: A Critique of Representation of Rural Women in Contemporary China. China: Lingnan University.

Wellek, Warren. 1984. Theory Of Literature new Revised Edition. New York: Hartcourt, Brace and World. 